\title{
School Dental Health Programs - A Way to Meet the Unmet Oral Health Needs
}

\author{
Vinej Somaraj* \\ Department of Public Health Dentistry, Rajas Dental College \& Hospital, India
}

Submission: July 27, 2017; Published: November 28, 2017

*Corresponding author: Vinej Somaraj, Senior Lecturer, Department of Public Health Dentistry, Rajas Dental College \& Hospital, Thirurajapuram, Kavalkinaru Junction, Tirunelveli District, Tamil Nadu, India, Tel: +918105170815; Email: v2vinej@gmail.com

\section{Abstract}

School health is an important aspect of any community health programs. It is an economical and powerful means of raising community health in future generations. School based oral health programs give children a chance to experience optimal oral health, but developing relevant programs that address the needs of today's children is a complex task. Our increasingly heterogeneous society possesses challenges to the school health program planner. Shifting demographics and attendant cultural diversity present a patchwork of societal and psychosocial variables that influence planning decisions. School based oral health programs that are designed to help children must be relevant and offer interventions based on current research findings. Schools provide an opportunity for learning new things that make them suitable for the presentation of oral health information.

Keywords: Education; Health; Health services; Oral health; School

\section{Introduction}

The most commonly seen and globally widespread diseases are oral-health related diseases. Untreated dental conditions and poor oral health have got a detrimental impact on the quality of life among school-going children which in turn affects the general health too $[1,2]$. The delay in treatment of oral diseases not only aggravates the condition but also increases the burden of diseases in terms of cost for treating it [3]. The likelihood of missing active school hours is 12 times more in children with poor oral health [4].

\section{Importance of Oral Health}

Annually more than 50 million active school hours are lost from due to oral diseases. Though dental caries and gingival diseases are most commonly seen among schoolchildren worldwide, other oral diseases or conditions like dental trauma, developmental dental defects, erosive conditions and oral cancer are of great clinical significance. Premature loss of deciduous dentition due to dental caries or any other reasons lead to malocclusion of the permanent dentition, thus causing a detrimental effect on the facial appearance of a child. Early tooth loss to affects the nutritional intake of a child which affects the growth and development $[5,6]$.

\section{School Dental Health Programs}

Schools lay down the base for education, developmental and behavioural patterns of a child. A school-going child being in constant company with his/her peers explores the health as well as oral health concerns under the guidance of professional educators. Schools offer a large workforce of teachers who educate schoolchildren at their crucial age and stage of growth and development [7]. Schools form the foundation for learning new things for the school-going children which they receive in a suitable form of a presentation about health and oral health related information. Schoolchildren are the foremost potential recipients of health related education as they spend a considerable amount of time in the school environment. Schoolchildren's habit can be intercepted as well as prevented and modification in a school environment as it is more suitable and comfortable for them rather than an unfriendly atmosphere like dental clinic [4]. School health services contribute to both the education system and health delivery care system. Coordinated school oral health programs offer the opportunity to provide the schoolchildren with services and knowledge necessary to be productive learners and to develop the skills to make health care related decisions for the rest of their lives [7]. School Health Education Programs designates to the provision of a safe and healthy environment for the establishment of interpersonal relationships favourable for emotional, social and physical health development [8,9]. Various School Dental Health Programs carried successfully around the globe can be enlisted: 
Save Our Smiles (Screening and Sealant Programme)

i. Learning About Your Oral Health

ii. Tattle Tooth I Program

iii. Tattle Tooth II Program

iv. THETA Program

v. Yukon Children's Dental Health Program

vi. Askov Dental Program

vii. St. David's Dental Program - A Mobile School-Based Dental Program For Children

viii. Bright Smiles, Bright Futures

ix. Healthy Mouth, Healthy Body

\section{Health-Promoting School}

A Health-Promoting School views "health" as physical, social and emotional well-being. It builds health concepts into all aspects of life at school and in the community. Different schools around the world have distinct needs and strength and it varies with areas and region. The heart of the process of becoming a Healthpromoting school relies on the fact that each and every school can find a way to improve not only the general health but also the oral health of students, parents and teachers. The health-promoting school uses its full organizational potential to promote health among students, staff, families and community members $[10,11]$.

\section{Incremental Dental Care}

It may be defined as "Periodic care so spaced that increments of dental disease are treated at the earliest time consistent with proper diagnosis and operating efficiency, in such a way that there is no accumulation of dental needs beyond the minimum" [12].

\section{Comprehensive School Health}

Comprehensive School Health is defined as "a broad spectrum of programs, policies, activities and services that take place in schools and their surrounding communities." This concept not only modifies individual behaviour but also enables one to modify his/her environment. Comprehensive School Health Education is a plan for school-going children and their families to learn a positive aspect of health. Comprehensive School Health Education Program institutes sequential and comprehensive health education lessons at each level of school education to address the general as well as the oral health of an individual. This program ensures involvement of families and communities to address critical health areas that put one at risk. Comprehensive School Health Education
Program is a multidisciplinary, planned, sequentially coordinated community program which ensures services of maximum quality and effectiveness which promote the emotional, social, educational and physical development of schoolchildren $[7,10]$.

\section{Conclusion}

Schools provide an important setting for oral health promotion, as they reach over a billion children worldwide. Through schoolchildren, the school staff, families and the community as a whole are benefitted from the oral health programs carried out at schools. Oral health promotion messages can be imparted as well as reinforced throughout the most influential stages of a child's lives, enabling a school-going child to develop lifelong sustainable attitudes and skills at schools. Poor oral health can have a detrimental effect on children's quality of life as well as the oral-health quality of life and in turn affect their performance at school and their success in later life.

\section{References}

1. Petersen PE (2003) The World Oral Health Report 2003. Continuous improvement of oral health in the 21st century- the approach of the WHO Global Oral Health Programme, WHO, Geneva, Switzerland.

2. WHO Information Series on School Health (2003) Oral Health Promotion: An Essential Element of a Health-Promoting School. WHO, Geneva, Switzerland.

3. Retna KN (2000) Assessment of dental treatment required and analysis of cost in the management of dental caries among semiurban primary school children of Kerala. J Indian Soc Pedod Prev Dent 18(1): 29-37.

4. Kwan SYL, Petersen PE, Pine CM, Borutta A (2005) Health-promoting schools: an opportunity for oral health promotion. Bulletin of the World Health Organization 83(9): 677-685.

5. Hiremath SS (2011) Textbook of Preventive and Community Dentistry. $\left(2^{\text {nd }}\right.$ edn $)$, New Delhi, India.

6. Texas Dental Association (2008) Building better oral health: a dental home for all Texans. Tex Dent J pp. 1-56.

7. Marya CM (2011) A Textbook of Public Health Dentistry. New Delhi: Jaypee Brothers Medical Publishers, India.

8. Dunning JM (1970) Principles of Dental Public Health. (2 $2^{\text {nd }}$ edn), Hardvard University Press, Cambridge, US.

9. Park K (2015) Park's Textbook of Preventive and Social Medicine. (22 ${ }^{\text {nd }}$ edn), Banarsidas Bhanot Publishers, Jabalpur India.

10. Peter S (2013) Essentials of Public Health Dentistry. ( $5^{\text {th }}$ edn), Arya Medi Publishing House, New Delhi, India.

11. WHO (2000) Local Action Creating Health Promoting Schools. WHO, Geneva, Switzerland.

12. Mythri H, Ananda SR, Chandu GN (2012) "A Journey of Thousand Miles Begins With A Single Step"-An Adage For Incremental Dental Care. IJDS $4(2)$ : 90-92. 
This work is licensed under Creative Commons Attribution 4.0 Licens

DOI: 10.19080/ADOH.2017.06.555685
Your next submission with Juniper Publishers will reach you the below assets

- Quality Editorial service

- Swift Peer Review

- Reprints availability

- E-prints Service

- Manuscript Podcast for convenient understanding

- Global attainment for your research

- Manuscript accessibility in different formats ( Pdf, E-pub, Full Text, Audio)

- Unceasing customer service

Track the below URL for one-step submission https://juniperpublishers.com/online-submission.php 